\title{
NPM Reforms in Ghana's Public Sector Management \& Administration: Changing Trends in MDAs \& MMDAs Functions
}

\author{
Nick Fobih \\ Department of Management, School of Business \\ University of Cape Coast, Cape Coast, Ghana \\ E-mail: nfobih@gmail.com
}

Received: Sep. 13, 2020 Accepted: Oct. 2, 2020 Online published: Nov. 18, 2020

doi:10.5296/jpag.v10i4.17955 ～URL: https://doi.org/10.5296/jpag.v10i4.17955

\begin{abstract}
The purpose of the study is to examine the new public management (NPM) reforms in Ghana's Ministries, Departments and Agencies, and at the local government level in terms of key changes implemented and its successes. The study also examines the challenges that have been encountered in the implementation process and recommendations to address the weaknesses in the system. The methodology used is based on the qualitative approach and the descriptive method. The findings in the study show that regardless of the in-roads made since the introduction of the NPM reforms, a number of challenges such as lack of expertise, lack of political will, inadequate resources among others, continue to affect the performance of Ghana's civil service, which in turn, impact the delivery of public services. The study recommends that NPM reforms must seek to increase levels of accountability because monitoring the performance of key institutions will go a long way to promote efficiency and effectiveness in the public service. The significance of the study is that it provides key insights into important issues in Ghana's NPM reforms, which can serve as useful tools for decision makers in moving the reforms towards accomplishing its goals more successfully. The outlined challenges and recommendations will inform the government, key policy makers and local government officials to enable them address the challenges affecting the effective implementation of NPM reforms. This study further contributes toward academic discussions relating to the impact of NPM reforms in Ghana and Africa in general.
\end{abstract}

Keywords: Ghana, MDAs \& MMDAs, NPM reforms, public sector management \& administration 


\section{Introduction}

The period prior to the introduction of the new public management (NPM) reforms in Ghana witnessed a number of major managerial and administrative challenges in the public sector such as financial and project mismanagement, lack of transparency and accountability, public funds embezzlement due to widespread corruption among both politicians and civil servants, inefficiency and ineffectiveness in the delivery of public services among others. These public sector challenges were predominant within the Ministries, Departments and Agencies (MDAs), and the local government system and institutions, particularly the then Local Councils, which were renamed as the Metropolitan, Municipal and District Assemblies (MMDAs) under the 1987/88 local government decentralisation reforms. In the late 1970s and 1980s, there was a paradigm shift in ideology in the global political economy from the Keynesianism development model (that supported the primary role of the state-led development in command economies) to neoliberalism (which emphasize the predominant role of the market). With the emergence of neoliberalism in the 1990s, new theories of public management such as managerialism, public choice, new public management, and reinventing government theories emphasizing incentives, competition, privatisation and performance emerged. These new paradigms were introduced to correct the deficiencies in public sector management systems (Bekkers, 2010; Simpson, 2012, Barzelay, 1992). The emergence of managerialism and NPM displaced traditional public administration's reliance on rule-based hierarchies in the implementation and performance of administrative functions (Hughes, 2003/2013; Armacost, 2000). The NPM approach therefore contrasts with the traditional public administration model in which institutional decision making, policy making and public service delivery are guided by regulations, legislation and administrative procedures. Since the 1990s, most developing countries including Ghana have adopted widespread programmes of public sector reforms.

Under the NPM reforms, public servants are regarded as public managers and citizens are viewed as customers. The theory also realigns the relationship between public service managers and their political superiors by making a parallel relationship between the two. NPM sets clear performance targets for public managers, which are assessed by using performance evaluations, with matching incentives-based motivation such as pay for performance. Managers are also given greater discretionary powers and freedom to make certain key decisions in the performance of their duties to achieve set targets and goals. The administrative failures which the public sector reforms sought to address include weak public financial management system, reporting and accountability, poor implementation of policies, weak monitoring and evaluation systems, low motivation and poor work ethics leading to low public service morale in service delivery among others. The goal of the NPM approach implemented by the government of Ghana (GoG) and its public service institutions and agencies, was to make the public sector look more "business-like" in order to enhance public sector efficiency and effectiveness in the running of public organisations at both the national and local government levels. The new paradigms also emphasize the need for greater coordination of government activities, combined with mechanisms to encourage greater performance and accountability in the MDAs, and within local government systems and 
institutions, particularly the MMDAs. The questions to be addressed in the study are; how has the implementation of NPM reforms improved MDAs and MMDAs service delivery? How have NPM reforms promoted efficiency and effectiveness in governance and public policy making? What changes have been effected and to what extent are they successful? And what are some of the major challenges hindering the success of the NPM reforms in Ghana? This study argues that the despite significant in-roads that have been made since the introduction of the NPM reforms, there still exist some major financial management and administrative challenges to overcome in order to achieve the objectives and goals of the reforms more appropriately.

\section{Literature Review}

Many scholars have discussed NPM from different perspectives in terms of the impact of the reforms on efficient and effective governance, managerial performance and socio-economic development. In reviewing the literature, four schools of thought are discussed, namely managerialism, public choice, NPM and reinventing government theories. Managerialism is a collection of beliefs and practices about management. Some advocates of managerialism and the public management movement (Pollitt, 1990; Enteman, 1993), argue that managerialism's main focus are:

- Organisations, both private and public, are best run when power is exercised hierarchically by managers who are distinct from the producers of goods or the providers of services, but have general power to dispose of the organisation's resources.

- Managerial discretion and increased autonomy for managers - which implies letting managers manage without political influences. In other words, empowering managers and giving them the freedom and leverage to manage public organisations. Therefore, entrepreneurial management is exploring managers' creativity and innovative abilities to manage the public sector effectively.

- Promoting accountability for results - giving managers responsibility and requiring them to be accountable to all stakeholders.

- Government should "steer rather than row" - directing managers and monitoring the private sector's service delivery performance.

The underlying assumption of the managerialism model is that the public interest is best identified and carried out by semi-autonomous and objective technocrats, who must be insulated from the influences of the executive and legislative bodies, allowing them to make implementation decisions that are unbiased by interest groups. Alongside managerialism emerged a second school of thought known as the public choice theory, which advocates the use of economic tools to deal with traditional problems in the public sector emphasizing privatisation, contracting out and public-private partnerships (Tullock, 1987; Buchanan, 1990). 
A third school of thought relates to the ideas propounded by advocates of new public management. Following the emergence of the managerialism theory, Hood (1991), coined the term new public management in his work. Just as the managerialism theory, NPM represents a major shift from traditional public administration with far greater attention to the achievement of outcomes, results, impacts and the personal responsibility of managers. As a performance-oriented approach to public management, NPM implies that the public sector is not distinct from the private sector. Public managers are assured to be entrepreneurial rational actors who in their pursuit of their interests create public value much as actors in private markets do. Advocates of NPM argue that introducing relatively uniform, market-like incentives such as competition and rewards proportional to performance would produce more accountability. In this case, establishing and implementing public policy in a neoliberal environment can be best achieved by applying management techniques developed in the private sector to reform the outmoded public sector organisational practices. NPM is therefore, a linkage of public demand, provision, and supply units by transactional devices (performance management, internal contract management, corporatisation, intergovernmental relations based on fiscal decentralisation and contracting out) and quality management. Hence there has been increasing retreat of bureaucratic government institutions in favour of markets and commercial market enterprises (deregulation, privatisation, commercialisation and marketization) or virtual markets (internal competition benchmarking, competitive tendering). Batley and Larbi (2004), pointed out that NPM ideas can be categorized into different strands, emphasizing managerial improvement and restructuring, which includes decentralisation, disaggregation and downsizing. NPM reforms agenda aimed at the following:

- Introducing private sector management strategies and business-oriented approaches into the public sector to make it look more "business-like".

- Increasing competition to offer citizens more choices, and give a greater voice to the users of public services, construed as customers.

- Improving the provision of goods and services and delivering them more effectively and efficiently to give citizens better value for money.

- Introducing a variety of market mechanisms -privatization, contracting out, and competition for higher performance in the public sector.

- Tightening and streamlining the management of public bureaucracies by re-organising government departments and central-local financial relations.

- Increasing citizen participation in political and administrative processes.

- Restructuring traditional boundaries of local government to enhance performance.

- Mastering techniques and procedures of administrative decision-making and control.

- Changing the definition of merit to reform hiring processes based on the merit principle.

- Promoting monitoring and evaluation systems for efficiency to reduce wastage.

- Introducing technological innovation into the private sector through the implementation of e-government in service delivery.

- Redefining the relationship between democracy and accountability. 


\section{Macrothink}

Journal of Public Administration and Governance

- Reducing corruption, and promoting administrative ethical standards and professionalism through new codes of conduct and new rules for ethical behavior for public service employees.

- Introducing a new accountability framework for public servants -accountability and responsibility of senior civil servants, and restructuring of the civil service and government organisations.

- Reducing bureaucratic bottlenecks, red-tapeizm and unnecessary delays in processes, thereby increasing the quality of service delivery.

- Redefining the relationship between the executive branch of government and the bureaucracy that works under the executive.

(Hood, 1991).

Holmes and Shand (1995), described NPM as a good managerial approach and result-oriented (efficiency, effectiveness and service quality), since it is intended to improve the quality of public services. Minogue (2001), also noted that NPM has brought benefits of cost efficiency and service effectiveness to public management, which is improving efficiency and obtaining value for money by focusing on performance management and auditing. NPM reform strategies have become the benchmark theory for the global administrative and management reforms agenda, which sets the stage for analyses of how public policy is actually set within the context of government and bureaucracy, and has changed the focus of service delivery from process-orientation to results orientation.

A fourth school of thought, which is termed as the reinventing government machinery is the process by which the progressive movement's philosophy of continuous improvement is pursued to make the running of government less expensive and more efficient. Its goal is to change the culture of the bureaucracy from complacency and entitlement to initiative and empowerment. Popularly known as the reinventing government theory, advocated by Osborne and Gaebler in their 1992 work, Reinventing Government: How the Entrepreneurial Spirit is Transforming the Public Sector, it added new enthusiasm to the on-going public sector reforms. To promote government efficiency and effectiveness in public sector, governance, advocates of the reinventing government view proposed the development of an "entrepreneurial government" in terms of reducing government expenditure/spending and/or waste in government offices. Thus, entrepreneurial government is a government that can compete and must compete with for-profit businesses, non-profit agencies, and other units of government. The authors' notion of entrepreneurial government based on the ten principles is that government should be:

- Catalytic - steering rather than rowing

- Community-owned - empowering rather than serving

- Competitive - injecting competition into service delivery

- Mission-driven -transforming rule-driven organisations

- Results-oriented-funding outcomes and impact, not inputs.

- Customer-driven -meeting the needs of the citizens, not the bureaucracy.

- Enterprising -earning rather than spending. 
- Anticipatory -prevention rather than cure.

- Decentralized -from hierarchy towards consultation, participation and teamwork.

- Market-oriented-leveraging change through the market system

(Osborne and Gaebler's, 1992).

The implementation of this theory led to government reforms and cost-savings in many countries, especially in the USA in the 1990s under President Clinton's administration. It is worth noting that while the above theories have significantly contributed towards reforming Ghana's management and administrative systems and institutions in its public sector, many challenges remain, especially in terms of reforming the government and its institutions to reduce public expenditure and promoting efficiency and effectiveness in the MDAs and MMDAs public service delivery activities.

\section{Methodology}

The research design was based on the qualitative study method and the descriptive approach, and used a combination of primary and secondary data collection method. Primary data was collected based on unpublished reports from government sources, mainly from the MDAs and MMDAs. Secondary data was also gathered from facts on Ghana's NPM reforms from academic journals and textbooks. For the purpose of this study, the population used includes public officials, organisations and citizens within selected regions in Ghana. As Creswell (2013 \& 2014), noted a study population is a group of individuals with some common defining characteristic that the research can identify and study. As a fair representation, the study used a sample size of ninety-three (93) respondents based on stratified random sampling in conjunction with convenience sampling. The study used thirty (30) Metropolitan, Municipal and District Chief Executives (MMDCEs) from the MMDAs, thirty(30) officials from the MDAs, thirteen (13) members of the Ashanti, Eastern, Central, and Western Regional Coordinating Councils (RCCs), and twenty (20) opinion leaders in the selected regions and MMDAs.

The survey method was used in collecting data from respondents, which is a method of data collection where information is gathered through questionnaires and interviews as major instruments to elicit information from the respondents. A combination of individual and focused group interviews were used to gather information from participants. These include structured and unstructured interviews consisting of open-ended and closed-ended questions. The five point Likert scale (a psychometric response scale) was used in both the interviews and questionnaires. Questions were outlined from one to five, where one represents the lowest score and five represents the highest score based on strongly agree -5 , agree-4, somewhat agree or indifferent -3 , disagree -2 and strongly disagree-1. Completed questionnaires from the fieldwork were edited and coded appropriately to make effective meaning out of the data. Editing was done to correct errors, check for non-responses, accuracy and correct answers. Coding was also done to facilitate comprehensive analysis of the data. The study also followed ethical guidelines and full disclosure of the purpose of the 
study, and ensured the confidentiality and anonymity of all participants.

\section{Research Findings: Key Changes and Challenges in the Implementation of NPM Reforms in Ghana}

\section{Key Changes in NPM Reforms in Ghana's MDAs \& MMDAs}

Generally, NPM reforms focused on promoting efficiency and effectiveness in the MDAs and MMDA. Since the adoption of NPM in Ghana's MDAs, the public sector has been reformed in terms of structure and process. Under the reforms, the country has pursued more rapid development initiatives by moving to a new functional model in a way that public sector organisations operate more like private sector organisations. In the MMDAs at the local level of government machinery, different mechanisms for promoting efficiency and effectiveness such as political, fiscal, economic, and administrative decentralisation (deconcentration, delegation and devolution) have been introduced. The following are some of the specific administrative changes introduced under the NPM reforms:

\section{Ghana Integrated Financial Management Information System (GIFMIS):}

GIFMIS is an information technology based system for budget management and accounting that is being implemented by the Ghana government. The introduction of GIFMIS in the NPM reforms seeks to improve the effectiveness and efficiency of Ghana's public financial management whilst reducing corruption and misappropriation of public funds within public institutions. According to the government of Ghana's 2000 report, GIFMIS is intended to improve public expenditure management processes, enhance greater accountability and transparency across MDAs and MMDAs, and to serve as an instrument for eradicating weak governance and corruption. As Yeboah, (2015) noted, GIFMIS was launched to replace the Budget and Public Expenditure Management Systems (BPEMS). Some reports show that GIFMIS is an improved system from past experiences of BPEMS. Key users of GIFMIS in the MDAs and MMDAs include budget officers, accountants, procurement officers, administrators and human resource managers (MDAs \& PPMEs Report, 2000-2020).

\section{Composite Budgeting at the Managerial and Administrative:}

In the pre-reform era, Ghana was faced with a myriad of challenges with regard to dysfunctional governance, poor budgeting and mismanagement of financial systems that resulted in weak delivery of vital public services. Poor budgeting systems led to undesirable challenges in terms of poor access to public services by citizens and communities, especially at the local government level. Composite budgeting is the integration of all the financial plans of decentralised departments into the MMDAs budgets. Warrant preparation, which is a financial requirement that gives a person the authority to spend under the approved budget were previously prepared in the MDAs and transmitted through Regional Directorates of Controller and Accountant-General to the MMDAs. The activity based budgeting has been in existence since 1998 to control leakages within the budgeting systems of the MMDAs budgeting proceedings, but the system faced many administrative challenges. As a result, a 
new budgeting system was introduced in selected districts across the country in 2012, which later in 2016, was spread to all districts across the country. With the introduction of the composite budget system, warrants are prepared by the MMDAs locally, and district budget officers and budget analyst at the MMDAs level are responsible for the preparation of the warrants. MMDAs officers were restricted to the preparation of only the MMDAs supplementary budget. All warrants prepared are signed by the MMDAs' metropolitan, municipal and district chief executives (MMDCEs) to ensure that the MMDCEs are made aware of how monies are spent under their jurisdiction. Some of the successes in the composite budgeting system at the MMDAs level are, strong collaboration between the MDAs and MMDAs regarding project implementation, and the promotion of due-diligence, since the system allows for all processes to be completed before payment is effected, which is good for better financial management. It also promotes control because under the old system, MMDAs were not aware of how much resource allocation were made to departments for the implementation of programmes and projects (MMDAs Reports, 2001 - 2019, MLGRD).

\section{Local Government Service’s (LGS) Performance Management System (PMS):}

The local government services have developed and implementing an evaluation system known as PMS, which consists of performance contracts to improve institutional and staff capacity, competition, performance and service delivery. This is implemented for Regional Ministers and Regional Co-ordinating Directors in the Regional Coordinating Councils (RCCs), MMDCEs and their Coordinating Directors in the MMDAs as well as performance appraisal for all other staff of the LGS to perform efficiently to maximum capacity in order to meet targets, and enhance socio-economic growth and development. The programme was jointly organised by the Center for Democratic Development (CDD) Ghana, the United Nations Children Fund (UNICEF) in collaboration with the Ministry of Local Government and Rural Development (MLGRD). These organisations initiated a simple ranking tool for measuring the level of development in each of the MMDAs known as the District League Table (DLT). The DLT was initiated as a simple ranking tool for measuring the level of development in each of the 254 MMDAs. It ranks the 254 MMDAs in terms of their delivery across six key public service sectors namely health, education, governance, security, sanitation and water. It aims at strengthening social accountability in development in all the MMDAs to improve responsiveness in service delivery. Some of the successes of the local government service performance management system at the MMDAs level include creating a platform for the citizenry to demand accountability from the RCCs and MMDAs for improved service delivery, supporting the government to better understand and monitor development projects nationwide, giving citizens access to information and knowledge on their right to development in their districts, intensifying engagements with stakeholders and stimulating MMDAs staff to enquire and make comparisons on performance and service delivery (MMDAs Reports, 2001 - 2019, MLGRD). 
Public Financial Management Reform Programme (PUFMARP) PUFMARP is a bold and comprehensive medium term strategic programme aimed at addressing the public financial management issues identified in the Pubic Expenditure Reviews (PER) in the 1993/1994 fiscal years. To buttress PUFMARP, the Controller and Accountant General's Department established Financial Monitoring Units (FMUs) at the national and regional levels to ensure efficient and effective fiscal decentralisation. The main components of PUFMARP used in budgetary tracking include the Budgeting and Public Expenditure Management Systems (BPEMS), Fiscal Decentralisation (FD), Comprehensive Auditing, Revenue Management, Cash Management and Information Technology (IT) strategy and the MTEF.

\section{Medium Term Expenditure Framework (MTEF):}

The introduction of MTEF was one component of a broader PUFMARP project. The government of Ghana (GoG) introduced MTEF in 1996 to improve the contribution of the budgeting system in the promotion of sustainable development and the realization of Vision 2020. It was recognised that there was scope for improving the links between policy-making, planning and budgeting systems, and processes at the district and sector levels in central agencies and at the political level. As part of the PUFMARP initiative, MTEF is very much concerned with improving all phases of the policy, planning, budgeting and implementation cycle, namely:

-Planning

-reporting

•budget formulation

-parliamentary scrutiny

•budget implementation

-expenditure control

-financial management

- government decision making

- organisational performance

An important innovation under the Growth and Poverty Reduction Strategy (GPRS I \& II) implementation strategy to further enhance the monitoring mechanism, is to link the GPRS II policy objectives to the budget through the MTEF initiative. MTEF is a prioritized, broad based, integrated, multi-year budget preparation process backed by strategic plans. The main objective of the MTEF is to improve the planning and budgeting of public expenditures and thus contribute to strengthened fiscal policy formulation and implementation. Thus, the purpose of MTEF is to ensure that scarce resources are deployed to achieve GoG objectives in the most effective manner. The overarching objective of GoG is to improve the contribution that government makes to development outcomes. In terms of budget outcomes, MTEF is mainly intended to contribute towards:

-a more stable fiscal policy

-improved allocation of resources to, and spending on, strategic priorities

-more efficient and effective use of resources in the delivery of services to citizens

Specifically, MTEF seeks to ensure aggregate fiscal discipline, efficient resource allocation and resource use based on strategic priorities, efficiency and effectiveness of programmes and 
service delivery.

National Expenditure Tracking System (NETS):

To further strengthen public financial management, the government introduced the National Expenditure Tracking System (NETS) in 2000 as part of the PUFMARP initiative with the aim of tracking budgetary resources allocated and disbursed to MDAs and MMDAs. This has proven to be an effective mechanism in providing information for analyzing efficient use of public resources. Under the GPRS II and Millennium Development Goals (MDGs) and the Sustainable Development Goals (SDGs) monitoring and evaluation (M\&E) framework, this system has been further enhanced and made operational across all sectors. These initiatives have strengthened accountability to a greater extent, and improved reporting on domestic expenditure, which is based on the NETS accounting system and fully reconciled with the Bank of Ghana (BOG) bank statements on spending (outflows) from all MDAs (MDAs \& PPMEs Reports, 2000-2020)

\section{Local Economic Development (LED) Policy Reform in the Local Government:}

LED is an approach towards economic development, which allows and encourages the local people to work together to achieve sustainable economic growth and development, thereby bringing economic benefits and improved quality of life for residents in local communities. Over the past decades or so, Ghana has made significant efforts at reducing poverty levels and improving the living standards of vulnerable groups within the society through the implementation of policies such as the Livelihood Empowerment Against Poverty (LEAP) programme. The introduction of LED is therefore seen as an alternative development reform to fully harness the economic potentials of the MMDAs for job creation and poverty alleviation. Some important successes of LED include promotion of jobs within the MMDAs, supporting the establishment of local industries, empowering the youth to venture into entrepreneurship to set up their own small-scale businesses, encouraging partnership between the public and private sectors, and creating a conducive environment for the growth of businesses at the local communities. To buttress these local initiatives, the National Youth Employment and Entrepreneurship Development (NYEED) programme and Business Resource Centres (BRCs) have been established in various municipalities and districts across the country to promote entrepreneurship development (MMDAs Reports. 2001 - 2019. MLGRD).

Introduction of a systematic Monitoring and Evaluation $(M \& E)$ System and Harmonization of $M \& E$ Systems in the MDAs:

In the early part of 2000, a new monitoring and evaluation system was introduced into Ghana's MDAs project performance monitoring and reporting systems. The introduction of the National Results Framework (NRF) is a results-oriented change with a focus on three outcomes per MDAs. The three outcomes (setting indicators, monitoring baselines and achieving targets) have become the instrument through which performance of ministries are assessed based on outcomes in the framework. Section 12, sub-section 1(b) of the Civil Service Law, 1993, PNDC Law327, also established the Policy Planning, Monitoring and 


\section{Mll Macrothink}

Journal of Public Administration and Governance

ISSN 2161-7104

2020, Vol. 10, No. 4

Evaluation Divisions (PPMEDs) to coordinate and monitor programmes of the MDAs under Section 12, 29(b) of the same Law. Under Articles 86 and 87 of the 1992 Constitution of Ghana, the National Development Planning Commission (NDPC) is mandated to guide and coordinate the formulation of development plans and to undertake the M\&E of the country's development efforts. In addition, Section10, sub-sections 6 and 7 of the National Development Planning System Act 1994, Act 480 requires the MDAs to monitor the implementation of the Sector Medium Term Development Plan (SMTDP) and submit a monitoring report at intervals in the prescribed form to the NDPC. There is more rigorous and systematic monitoring and performance evaluation programme to find out whether or not government programmes are achieving their goals. The MDAs use colour-coding to indicate the progress or status of projects, with green indicating the project is completed, yellow showing the project is in progress, but has some challenges that are stated in the PPMEDs' reports, and red showing the project has stopped stating reasons why it's not working. At every stage of a project, the PPMEDs are tasked with the preparation of quarterly reports to the Office of the Chief of Staff in the Office of the President, through the Policy Coordination and Monitoring Unit (PCMEU), now Office of Delivery in collaboration with the newly established Ministry of Monitoring \& Evaluation. (Office of the President Reports, 2000-2018; MDAs \& PPMEs Reports, 2000-2020)

\section{E-government \& Digitisation of Public Services:}

The various MDAs have succeeded in digitizing various services aimed at improving their effectiveness and efficiency in service delivery. The introduction of e-government in the public sector has facilitated service delivery to accelerate client service processes and promote effective service provision. Access to information through technology is making accessibility to public services easier (Barata, \& Cain, 2011). Some of the services that have been digitised include the introduction of online biometric registration, the paperless ports processing systems, online National Health Insurance Scheme renewal, online business registration and payments, among others. All these services have improved leading to increase in revenue mobilisation, reducing bureaucracies and improving service delivery for citizens/client satisfaction (Office of the President Reports, 2000-2018).

\section{Privatisation, Performance Contracts, Contracting-out, Outsourcing \& Public-Private}

\section{Partnerships:}

Under the NPM reforms, a number of market-oriented reforms have been introduced in Ghana's public sector to push the sector towards achieving the goals of the reform in terms of improving efficiency and effectiveness. Privatisation policy has brought flexible labour relations, civil service reforms and retrenchment of unwanted staff, and/or removal of "ghost names from the Controller and Accountant General's payroll system, removal of subsidies and the introduction of user fees to reduce financial over-burden on the government. The government's privatisation policy involves the sale of shares or ownership of public corporations or state-owned enterprises or the government's operating assets or services. With the introduction of the government's divestiture programme in the 1980s and 1990s, privatisation has been most common and more widely accepted in sectors that are not 
traditionally considered strategic public services, mostly in public corporations such as manufacturing, construction, etc. Privatisation has also encouraged private sector development as the engine of growth of the economy and hence the creation of the free trade secretariat to enhance the in-flow of horizontal, vertical and conglomerate foreign direct investments (FDIs) into the country. Contracting out is also another element of NPM reforms. Contracting out has created the enabling environment for the private sector to bid for government contracts in service delivery, infrastructure development, supply, distribution etc. and is increasingly being adopted in the delivery of public services including utilities, transport, communication, sanitation etc. (Office of the President Reports, 2000-2018).

Outsourcing and contracting out are two terms that are used interchangeably. Outsourcing refers to contracting, sub-contracting or externalizing non-core activities to free up cash, personnel time and facilities for other activities. Government functions are more likely to face market tests; in separating the purchaser of government services from the providers (contracting out), that is, separation of "steering from rowing" (Savas, 1987). Since the 1980s, many functions that were the sole domain of MDAs have been contracted out and/or outsourced. As Hughes (2013) noted, there is a trend towards reducing government functions through privatisation and other forms of market testing and contracting, in some cases quite radically. Public-private partnership (PPP) also describes a range of possible relationships among public and private entities in the context of infrastructure and other services. PPP has a contractual agreement defining the roles and responsibilities of the government and the private sector, and involves risk-sharing between the public sector and the private sector partners, as well as financial rewards to the private party commensurate with the achievement of pre-specified outputs (Office of the President Reports, 2000-2018).

\section{Competition \& Competitive Tendering:}

One of the fundamental determinants of the efficiency of any arrangements is competition; that is the degree of competition that an arrangement permits will to a significant degree, determine how efficiently that arrangement will supply a service. Under the NPM reforms, competitive tendering in particular has been used by GoG in the award of contracts at the MDAs and MMDAs. The goal of competitive tendering is that competition between bidders is intended to spur efficiency gains and cost savings. The adoption of such practices is based on the view that planners remain the ultimate arbiters of resource allocation, but gains in productive efficiency can be achieved by some degree of competitive regulation. (MDAs \& PPMEs Reports 2000-2020). Besides, the establishment of the Public Account Committee (PAC) of parliament is to ensure transparency, fairness in the award of contracts and disbursement and usage of public accounts (Parliamentary Reports from Finance \& Budget Committee and Public Accounts Committee hearings, 2000-2019).

\section{NPM \& Improved Economic Performance:}

Fiscal restructuring under NPM reforms has led to increase in macro and micro economic indicators such as inflation, growth domestic product (GDP), interest rates, more effective tax system etc., which the country has experienced over the years. As reviewed in the literature, the productivity of civil servants has a positive or negative relationship with the economic 
conditions of Ghana. Ghana's economic recovery has a positive outlook as affirmed by rating agencies such as Standard and Poor (S\&P) Global Ratings, which rated Ghana's credit rating form 'B'- to 'B' with a stable outlook in September 2018 (www.bog.gov.gh). Also, inflation has steadily dropped over the years (Ghana Statistical Services Report, 2016-2019). All these economic progress and improved performance of civil servants can be attributed to fiscal reforms under NPM.

\section{Reform of Subvented Agencies (SAs) \& Improved Client Service Units:}

As part of the reforms, MDAs have been tasked to update and improve capacities of client service personnel in all ministries. The Department of Management in each MDA has been conducting training on quality client service delivery with focus on effectiveness and efficiency. Subvented Agencies are tasked to sign institutional performance contracts. The goal is to achieve operational effectiveness and efficiency in SAs (MDAs \& PPMEs Reports 2000-2020).

\section{NPM Implementation Challenges: Key Issues Facing the Implementation of NPM Policies in Ghana}

Despite the radical changes and the administrative and socio-economic benefits from the implementation of the NPM reforms, the following challenges were identified in the study:

- Reforms have to deal with complex political, administrative, structural/systemic and socio-economic challenges in the MDAs and MMDAs. Whereas some MDAs and MMDAs have pursued their deliberative, legislative, administrative and planning functions with vigor, others have not been able to catch-up with contemporary trends. Due to weak processes for integration into the Medium-Term Development Plans (MTDPs) of MMDAs, the positive impact of the NPM reforms in Ghana's public sector has not been felt in some sectors.

- Challenges associated with the implementation of GIFMIS include lack of skills in IT personnel at the local level to effectively use the system, delay in releasing funds for payment to debtors since it operates with poor internet and inadequate IT infrastructure in the public sector, especially problems with network connectivity in the local communities.

- The composite budgeting system faces many challenges because there is often undue delays in implementing the central government's fiscal policy and inter-governmental transfers, with regard to financial disbursements such as the District Assemblies Common Fund (DACF) to the MMDAs.

- Some key issues in the LED implementation are inadequate resource base for LED activities, low commitment of leadership of the MMDAs on timely responses to local entrepreneurs and practical efforts at promoting LED, lack of access to finance, absence of guidelines on LED at the national level, weak private sector involvement to engage public sector in the LED, informal nature of many businesses in Ghana to 
qualify and participate in the project, poor road-network or infrastructure to enhance quality service at the local level.

- Challenges in the implementation of the composite budget include the cost of paper to prepare warrants for all manner of payments, increasing the financial burden of the MMDAs, delay in plan preparations affects the budgeting processes, weak political commitment due to the reluctance of some politicians and bureaucrats to release funds to decentralized departments under their ministries. Some decentralised departments fail to submit inputs early enough for incorporation into the composite budget

- Some of the challenges in the implementation of the LGS in the PMS is that some MMDAs see the DLT as a name and shame mechanism. Another challenge is lack of autonomy of the MMDCEs to make bold and decisive decisions in the implementation of the LGS, due to the central government's overarching control.

- Public institutions are expected to run smoothly with less bottlenecks so as to serve the people, but the bureaucratic nature of Ghana's MDAs makes the NPM reforms slow, inefficient and ineffective. Most times, obtaining financial and logistical support to ensure effective implementation may delay as a result of chains of authorities/signatories in the release of funds allocated for a particular project.

- Lack of continuity in government policy is a major challenge for the success of the NPM reforms since every new government that assumes power is reluctant or unwilling to continue projects started by its predecessor government for various reasons.

- Ineffective information dissemination in intergovernmental relations, from the central government to local governments also affect the successful implementation of the NPM reforms. Despite the fact that dissemination of information on the goals and specific objectives of government policies and their implementation is very important for the success of projects, some MDAs fail to give information to the MMDAs on clearly outlining the latter's roles and responsibilities in the implementation of certain policies and projects.

\section{Conclusion}

It can be deduced from the above discussions that with the introduction of NPM reforms, Ghana's public sector has improved tremendously since the 1990s, however, it still requires a sustained and coordinated effort aimed at maximizing its benefits to the citizenry. It could be argued that the NPM reforms have improved performance, ensured transparency and accountability, created jobs at the local level, and increased consultation, participation and involvement in decision making as well as created an effective and sustainable operation of the MDAs and MMDAs that will stand the test of time. Nonetheless, there are many challenges to overcome in order to achieve the goals of the NPM reforms. Ghana's public sector is bedeviled with so many problems that the NPM reforms must be well-implemented 
to make the sector effective and efficient. It is worth noting that a serious political will is required of politicians and civil servants or political administrators at both the national and sub-national levels to continue the implementation of the NPM reforms in order to make the national and local governments deliver public services more effectively and efficiently.

\section{Recommendations}

- Some of the factors that have been identified as critical to the success of the implementation of GIFMIS include trust between partners, user involvement and participation, improving transparency and accountability, good project scope management in the GIFMIS and promoting due diligence in the system allows for all processes to be completed before payment is effected, which is good for better financial management. It also necessary to organize capacity building workshops for public sector workers periodically to improve their IT skills, and establish an independent network for the management of the GIFMIS system to work effectively. Establishing control systems will also make the MMDAs aware of how much resource allocation are made to their departments for the implementation of programmes and projects.

- Suggested solutions to the identified challenges in the composite budget implementation include a well-trained and motivated workforce for successful implementation of composite budgeting. The central government should ensure adequate transfer of financial resources to decrease the financial burden of the MMDAs. Decentralised departments should submit their inputs early enough for incorporation into the composite budget, and preparation plans should be done early in order not to affect the budgeting process. For a more successful implementation of the DLT, more stakeholder participation and sensitisation programmes should be organised for both MMDAs staff and citizens at the local level. The district composite budgeting system should facilitate revenue assignments and make the composition of revenues be based on the type of expenditure assignments at each level of government in the implementation of the inter-governmental fiscal framework. This should further be strengthened to facilitate local sustainable development in all MMDAs across the country.

- The NPM reforms must seek to increase levels of accountability, and monitor the performance of key institutions, which will go a long way to reduce corruption in the public service. The Ministry of Public Sector Reforms and the newly created Ministry of Monitoring \& Evaluation must be empowered to play oversight roles in the reform processes. There is a need to introduce development policy design assurance frameworks and identification of significant implementation risks and challenges along with risk management strategies to strengthen public sector and ensure successful implementation of the reforms.

- Finally, the study recommends that further research need to be conducted on the impact of NPM reforms in the respective sub-regions or generally on African countries' public sector management and administration, and socio-economic development. 


\section{References}

Armacost, M. H. (2000). Foreword. In Kettl, D. F. The global public management revolution: A report on the transformation of governance. Washington, DC: Brookings Institution.

Bank of Ghana. (2018). Ghana's Credit Rating for 2018. www.bog.gov.gh. September 2018. Cited on August10, 2020.

Barata, K., \& Cain, P. (2011). Information, not technology, is essential to accountability: Electronic records and public sector financial management. The Information Society, 17(4), 247-258.

Barzelay, M. (1992). Breaking through bureaucracy: a new vision for managing in government. Berkeley:University of California Press.

Bekkers, V. (2010). Reinventing government in the information age: International practice in IT-enabled public sector reform. Public Management Review, 5(1), 133-139.

Batley, R., \& Larbi, G. (2004). Changing approaches to public sector management: In the changing role of government (pp. 1-53). London: Palgrave Macmillan.

Buchanan, J. M. (1990). The domain of constitutional economics. Constitutional Political Economy, 1(1), 1-18.

Center for Democratic Development. (2018). District league table. Accra: Ghana. CDD.

Creswell, J. W. (2013). Qualitative inquiry: Choosing among five approaches.LA, CA: SAGE.

Creswell, J. W. (2014). Research design: Qualitative, quantitative and mixed methods approaches. London: Sage Publications.

Enteman, W. F. (1993). Managerialism: The emergence of a new ideology. Madison, WI: University of Wisconsin Press.

Government of Ghana. The 1992 Constitution of Ghana. Section 12, sub-section 1(b) of the Civil

Service Law. (1993). PNDC Law327, Section 12, 29 (b). Accra. Government of Ghana.

Government of Ghana. The 1992 Constitution of Ghana. Articles 86 and 87, Section10, sub-Sections 6 and 7 of the National Development Planning System Act 1994, Act 480. Accra. Government of Ghana.

Government of Ghana. MMDAs' Policy Planning, Monitoring \& Evaluation (PPMEs) Report 2000-2020, Accra

Government of Ghana. MMDAs Reports. 2001 - 2019. Ministry of Local Government \& Rural Development (MLGRD), Accra

Government of Ghana. Ghana Statistical Services Report, 2016-2019. Accra.

Government of Ghana. Parliamentary Reports on Public Accounts Committee Hearings, 
2000- 2019. Accra.

Government of Ghana. Office of the President Reports - 2000-2018. Accra.

Holmes, M., \& Shand, D. (1995). Management reform: some practitioner perspectives on the past ten years. Governance, 8(4), 551-578.

Hood, C. (1991). A public management for all seasons. Public Administration, 69(1), 3-19.

Hughes, O. (2003). Public value pragmatism as the next phase of public management. The American Review of Public Administration, 38(2), 130-148

Minogue, M. (2001). "The internationalization of new public management." In Willy McCourt \& Martin Minogue (ed.). The Internationalization of Public Management, Edward Elgar publishing.

Minogue, M. (2001). Should flawed models of public management be exported? Issues and practices. Chapters. Edward Elgar publishing.

Osborne, D., \& Gaebler, T. (1992). Reinventing government: How the entrepreneurial spirit is transforming the public sector. MA: Addison-Wesley Publishing.

Pollitt, C. (1990). Managerialism and the public services: The Anglo-American experience. Oxford: Blackwell.

Savas, E. S. (1987). Privatization: The key to better government. UK: Chatham House Publication.

Simpson, M. G. (2012). Making representations: Museums in the post-colonial era. USA: Routledge.

Tullock, G. (1987). Public choice. The new palgrave. A Dictionary of Economics, 3, 1040-1044.

Yeboah, S. K. (2015). Public sector financial management reforms in Ghana: The case of Ghana integrated financial management information system (GIFMIS) (Doctoral dissertation, University of Ghana).

World Bank. (2010). Ghana's new approach to public sector reform: Focusing on delivery. Washington, DC. () World Bank. https://openknowledge.worldbank.org

\section{Copyright Disclaimer}

Copyright for this article is retained by the author(s), with first publication rights granted to the journal.

This is an open-access article distributed under the terms and conditions of the Creative Commons Attribution license (http://creativecommons.org/licenses/by/4.0/). 